\title{
AVAILABILITY OF PSYCHOLOGICAL SUPPORT FOR MEDICAL STUDENTS IN POLAND
}

\author{
MACIEJ WALKIEWICZ ${ }^{1}$ and MATEUSZ GUZIAK ${ }^{2}$ \\ Medical University of Gdańsk, Gdańsk, Poland \\ ${ }^{1}$ Department of Psychology \\ ${ }^{2}$ Faculty of Medicine
}

\begin{abstract}
Objectives: Medical students suffer from a considerable level of stress, which can result in the deterioration of their mental health, including depression or suicidal ideation. They are afraid to seek help due to stigmatization and environmental ostracism. The goal of the study is to analyze the psychological support and stress management programs for students supported by medical schools in Poland. Material and Methods: The authors sent out e-mails with 9 questions regarding the issue being analyzed to all 19 medical schools in Poland. They obtained answers from 15 such schools, which corresponds to a response rate of 79\%. The study was conducted in 2018-2019, before the SARS-CoV-2 pandemic. Results: Due to the lack of central regulations, support is provided by medical schools individually. Those solutions focus on short-term, temporary therapy. If a longer therapy is needed, students are redirected to external health providers. Moreover, information about the support is not transferred by student-friendly communication channels. Conclusions: Support should be flexible, and it should quickly adapt to the emerging trends and consider students' feedback. A future model of psychological support could be a center organized as a transfer point between a university problem-solving facility and external health providers, concentrating on short-term activity. Quick support would eliminate potential complications and more serious mental problems. Int J Occup Med Environ Health. 2021;34(1):87-99
\end{abstract}

Key words:

mental health, support, psychological distress, medical students, medical education, preventive programs

\section{INTRODUCTION}

Medical staff experience a heavy workload and suffer from a considerable level of stress, which can result in the deterioration of their mental health and burnout [1-4]. The same applies to medical students, for whom the beginning of their studies is a particularly demanding challenge. The majority of them have to adapt to new living conditions, contexts and social spaces in their surroundings, usually without familiar support (e.g., from friends and family) [5].
In 2016, a systematic review and a meta-analysis of 195 studies involving 129123 medical students in 47 countries demonstrated that $27 \%$ of them screened positive for depression, and $11 \%$ reported suicidal ideation, during their medical education [6]. Only $16 \%$ of the students who screened positive for depression reportedly sought treatment. The possible causes of depressive and suicidal symptomatology among medical students are likely to include stress and anxiety related to the competitiveness of a medical school [7]. Moreover, the medical school

Received: September 13, 2019. Accepted: September 14, 2020.

Corresponding author: Maciej Walkiewicz, Medical University of Gdańsk, Department of Psychology, Tuwima 15, 80-210 Gdańsk, Poland (e-mail: maciej.walkiewicz@gumed.edu.pl). 
environment, which is conducive to the occurrence of the competition phenomenon, negatively affects students' desire to seek psychological support [5,8-11].

Some institutions (e.g., the Association of American Medical Colleges) emphasize the need to involve physicians' well-being in medical education programs [12,13]. The Journal of the American Medical Association (JAMA) Psychiatry suggests that national organizations should address mental health support for residents and fellows by proposing strategies for comprehensive education, screening and treatment [14]. Moreover, findings suggest that medical schools and health authorities should offer early detection strategies, prevention programs and interventions in regard to depression of medical students before their graduation [15]. Furthermore, medical students confirm this opinion. The American Medical Student Association suggests that mental illness monitoring and wellness promotion should take place as soon as medical education begins [16]. Medical students begin training with a level of mental health that is similar to, or better than, that of their peers. Therefore, the high rates of distress reported by medical students and residents support concerns that the training process and medical environment contribute to the deterioration of mental health [17]. What is more, there is a significant increase in the proportion of students at risk of perceived stress and depression during medical education [18].

\section{Medical education in Poland, its costs and perspectives}

There are 149103 medical doctors actively practicing in Poland (according to the Polish Chamber of Physicians) [19]. The analysis of the Organisation for Economic Co-operation and Development (OECD) shows that Polish doctors are among the most overworked in Europe. Furthermore, the number of practicing doctors in Poland in relation to the number of inhabitants is the lowest in the entire European Union, with 2.4 physicians per 1000 residents [20].
Medical training in Poland lasts 6 years. Graduates must complete a 13-month internship, providing medical assistance under supervision, mainly in a hospital setting. After passing the National Examination for Medical Doctors, they are given a license to practice as a general practitioner. The test results determine whether and which of the 77 medical specializations the young doctor will take during his/her further career. Postgraduate training lasts from 4 years (e.g., epidemiology, public health, family medicine) to 7-10 years (oncological gynaecology, intensive care, clinical transplantology).

Based on the data received by e-mail from the Department of Science and Higher Education of the Ministry of Health (January 2019), the total number of medical students in Poland is 29 783. Studies are free of charge. The Ministry of Health estimated that the average cost of a doctor's education (in the academic year 2017/2018) was about EUR 4500 per semester. Additionally, medical schools offer paid study programs in Polish $(\mathrm{N}=3923,13 \%)$ at a cost of EUR 3600 and provide for international students in English $(\mathrm{N}=6238,21 \%)$ at a cost of EUR 5100, while the average income in Poland is around EUR 830 monthly after tax [21].

The Polish Ministry of Health and the Polish Chamber of Physicians do not collect data about Polish citizens currently studying medicine abroad and physicians who work abroad. Nor do they verify the mental health condition of medical students and physicians.

Taking into consideration the data presented above, such as the low number of physicians and the cost of medical education, it must be said that medical students are an extremely valuable source for the Polish society.

\section{Objective of the study}

The objective of the presented paper was to analyze the psychological support and stress management programs for medical students currently supported by medical schools in Poland. 


\section{MATERIAL AND METHODS}

Initially, the authors made enquiries to the Ministry of Health, which is responsible for the process of educating Polish doctors. They asked whether data about Polish medical students' mental health are collected, and if there are any guidelines for the psychological support provided by medical schools. They discovered that the Ministry does not collect such data and there are no regulations in place. Therefore, all initiatives concerning the possible support are set out by each university individually. The authors then sent out e-mails with the following 9 questions regarding the issue being analyzed to all 19 medical schools in Poland:

1. Does the university provide psychological help for students and what form does such help take?

2. How can students make an appointment (by phone/via an online register form)?

3. Is the number of consultations/appointments limited?

4. Is the institutional unit or an external entity responsible for organizing the assistance, and what is the source of financing?

5. Is there separate (psychological) support for international/Erasmus students?

6. Where can students find information about potential help (an official website of the university/an internal network/social media)?

7. Are online consultations available (e.g., via Skype)?

8. Is it possible for the university's employees to receive help?

9. How many people take advantage of such support and what are the main reasons for consultations?

The first e-mails were sent directly to the deans of medical faculties, attached to the heads of dean's offices (November 27, 2018). Address information available on the official websites of medical schools was gathered and used. In parallel, the authors analyzed the official information about the psychological support for students that the universities presented on their websites. Then, after a month, they sent another e-mail and a traditional letter to the deans of those schools that had not yet responded. The correspondence was forwarded additionally to university press spokesmen, the departments of psychology and/or university disability support services if such information was presented on the official website. Finally, the authors received responses from 15 universities (a response rate of 79\%).

\section{RESULTS}

Due to the specific character of the obtained results, the authors decided to present them in the form of a table (Table 1).

\section{DISCUSSION}

\section{The general course of the study}

\section{and transfer of information}

It was quite surprising to learn that the Ministry of Health collected no information about the mental condition of medical students. Due to the lack of systemic, administrative and central regulations, the problem of psychological support was being solved by universities individually.

It is worth noting that some of these psychological support programs were created over the last 2 years. The creators of the most recent ones gave the authors the most complete and transparent feedback. Unfortunately, there were also public universities that did not respond, even though the authors repeated their e-mail requests and sent traditional letters. Additionally, information about the support available on the official websites of universities was analyzed.

\section{Applied solutions}

In general, the provided support is mostly temporary, consultative and interventionist. Later, if a longer therapy is needed, students are redirected to an external health provider. The current solution seems to be proper and justified in the authors' opinion. Due to the lack of central regulations, each university organizes the support indi- 


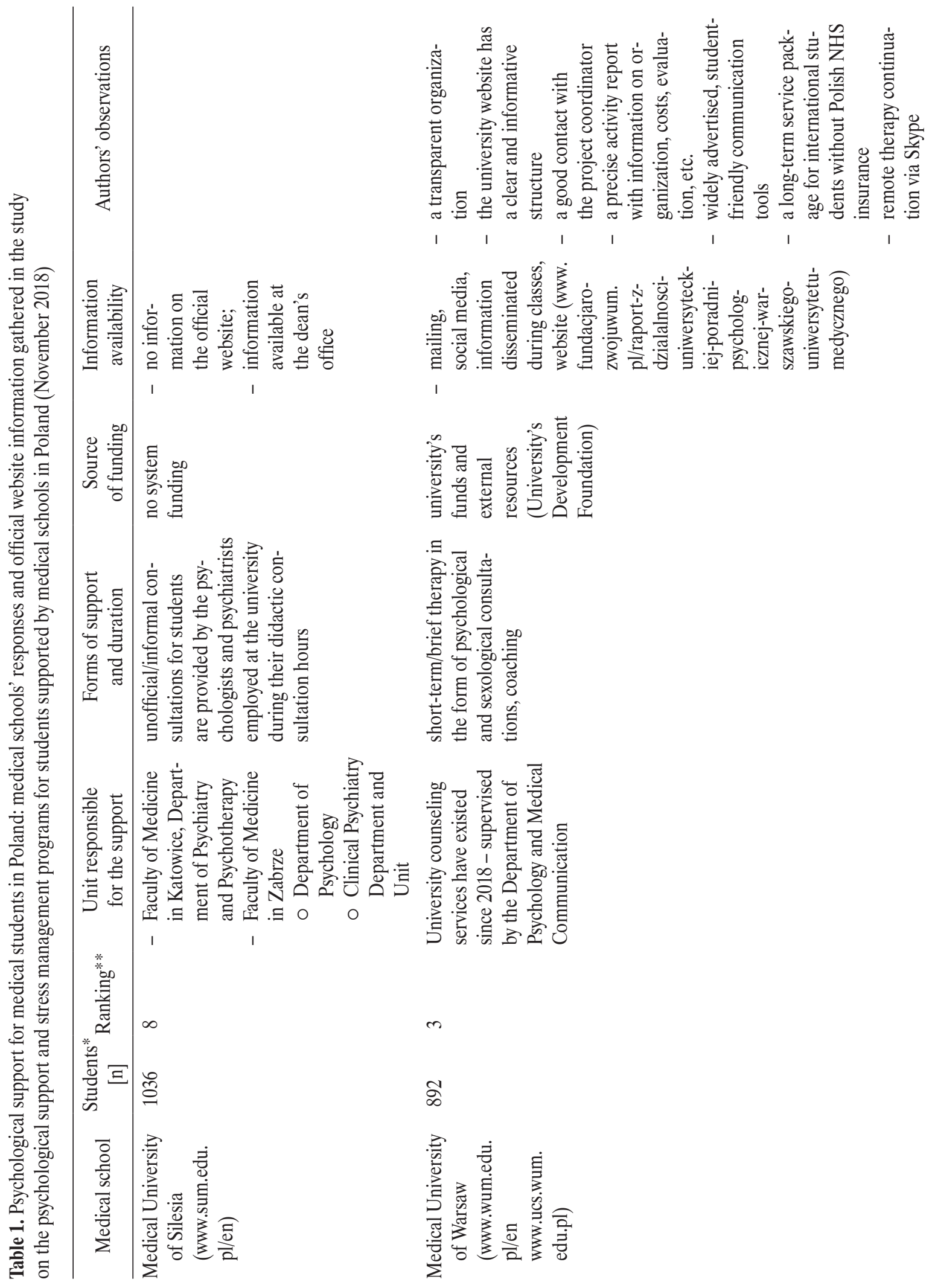




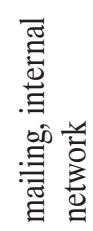

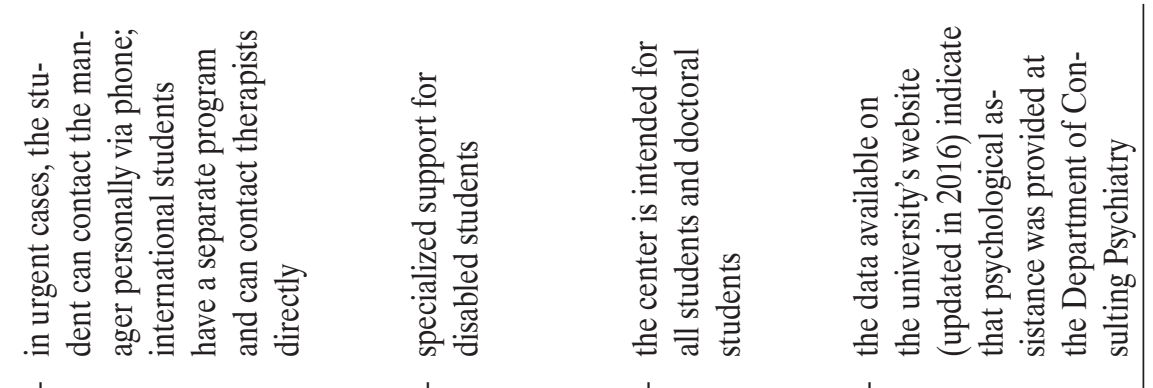

।
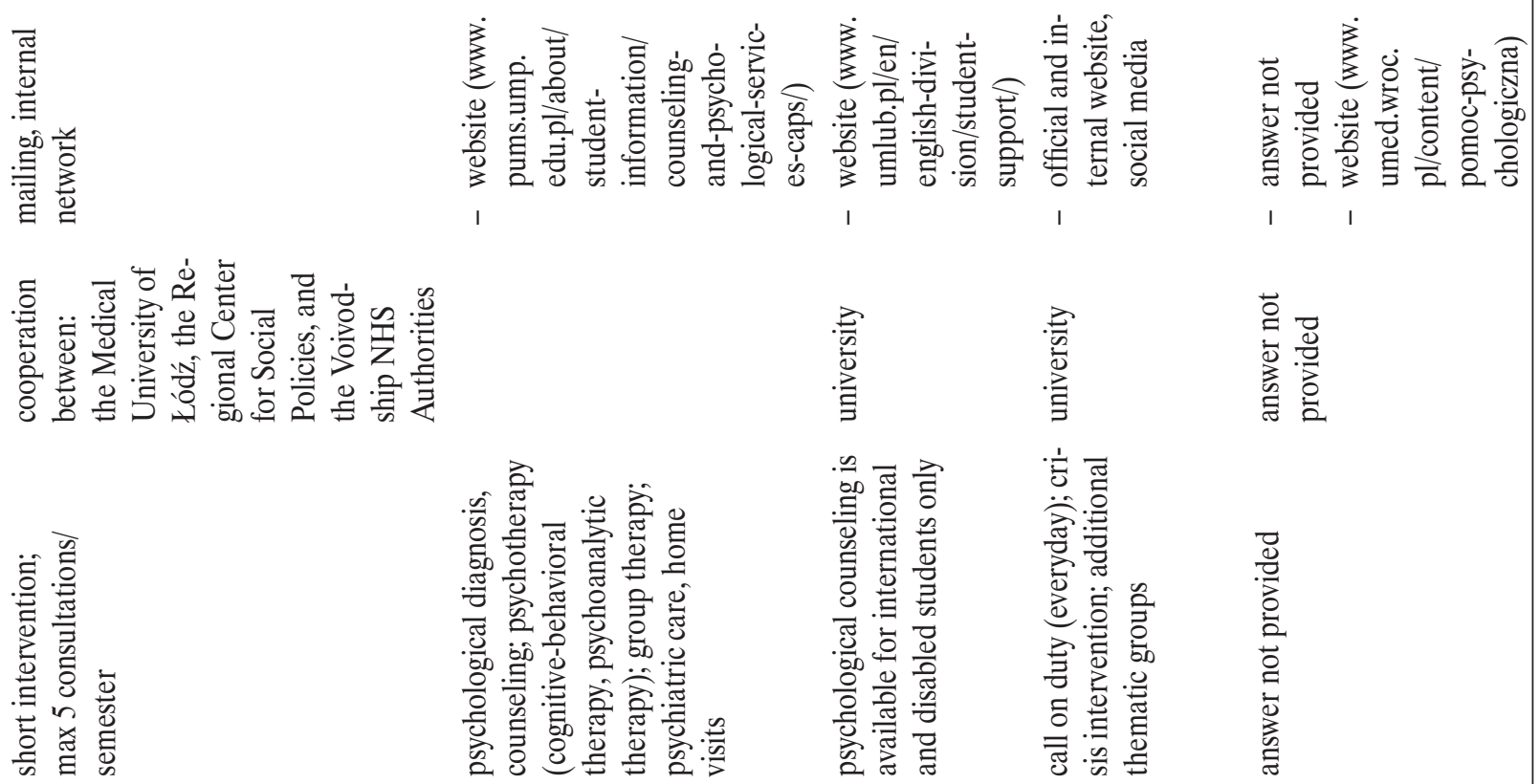

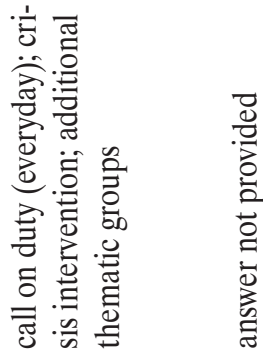
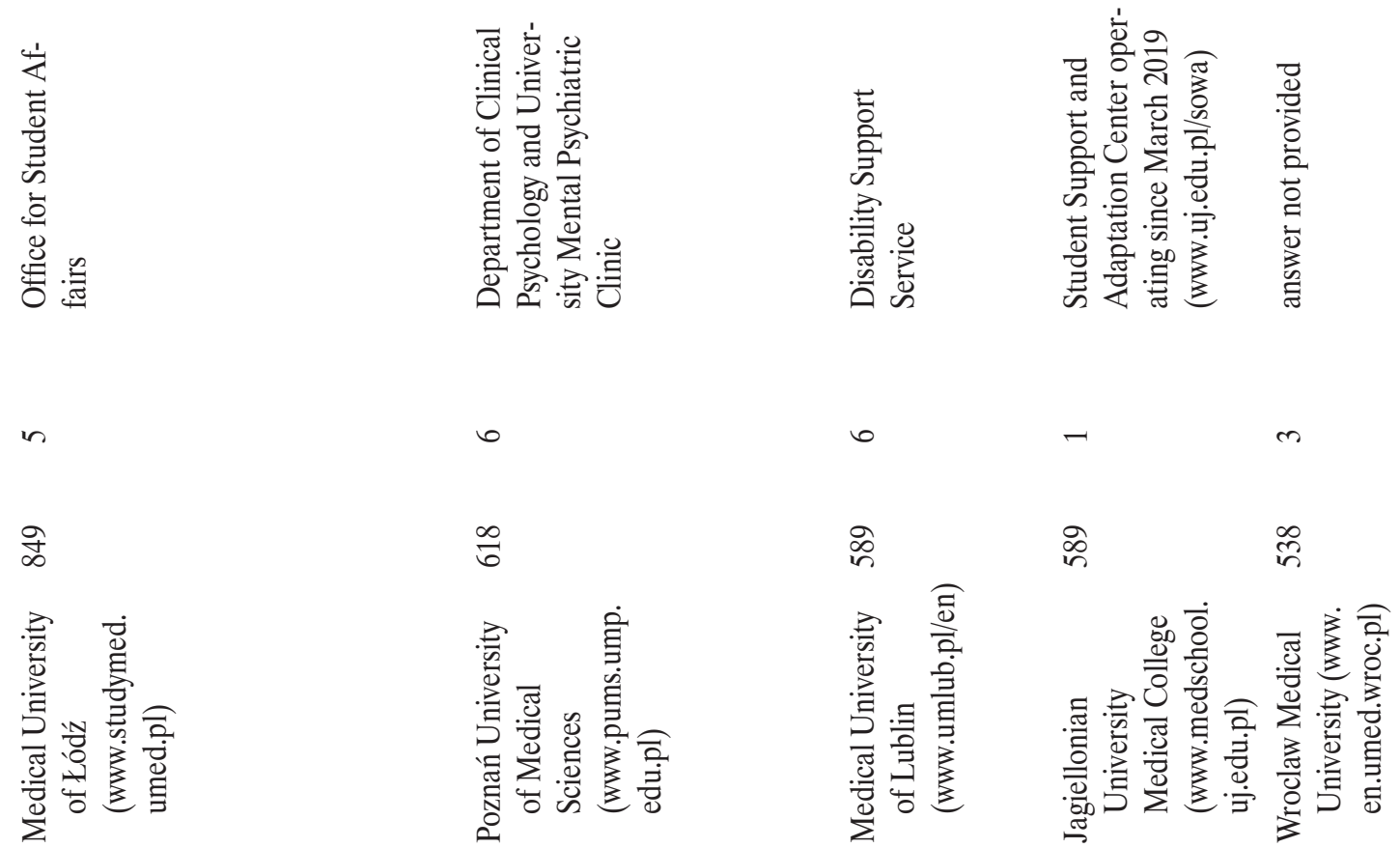


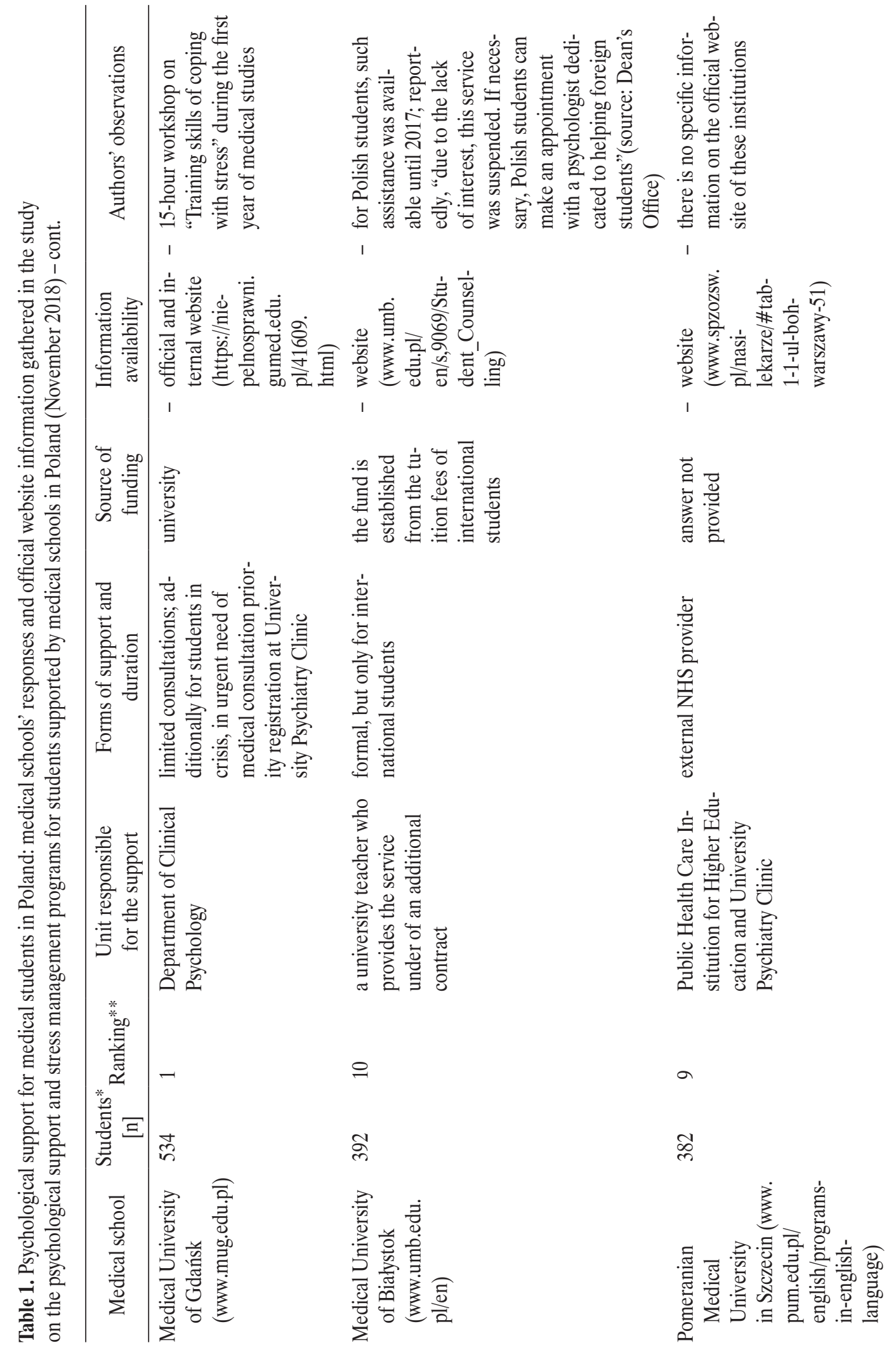



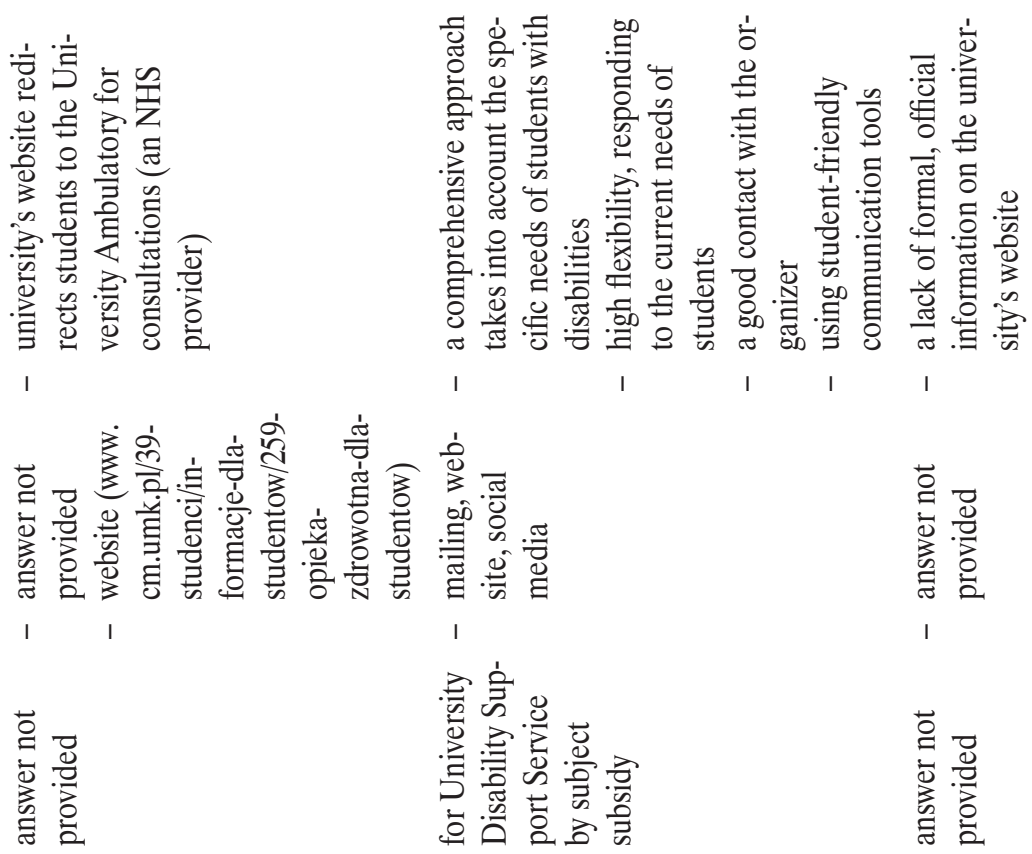

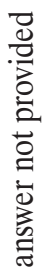

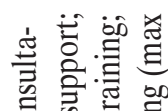

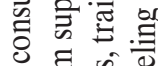

责 苍总

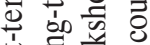

的产 总焉

苛言言:

$\because \cdot b_{0} . \Xi \approx$

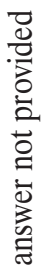

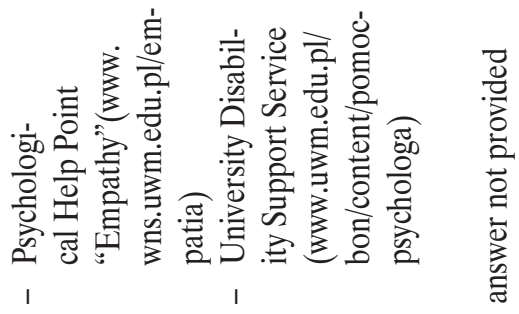

$=$

穴

శ్
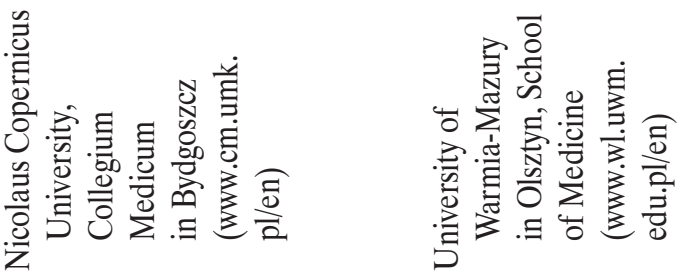

0
$\frac{0}{0}$
0
0
0
0
0
0
0

§

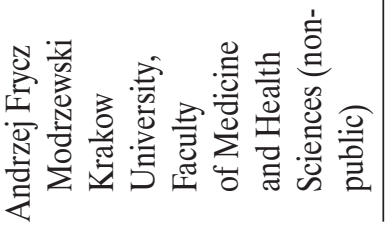




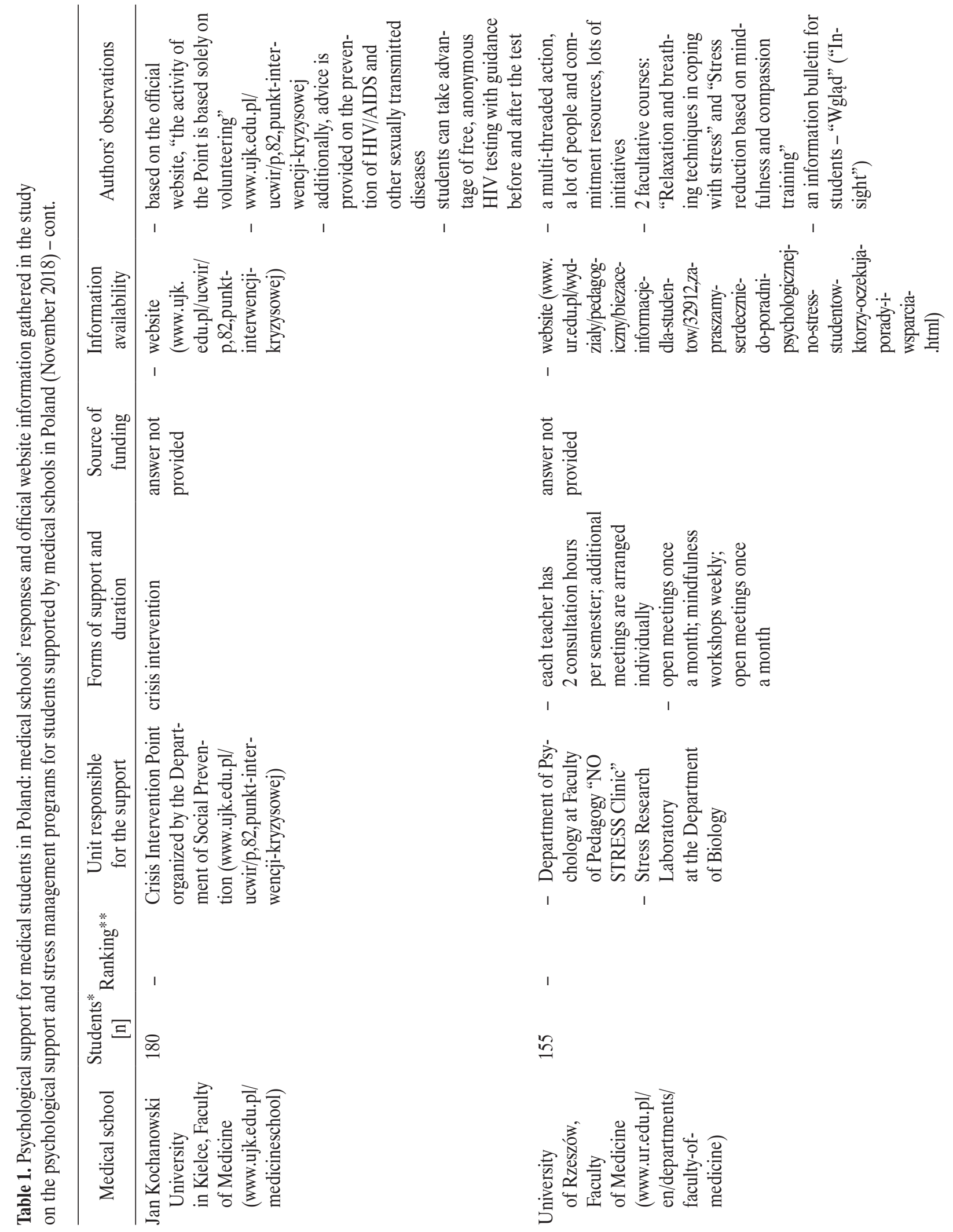




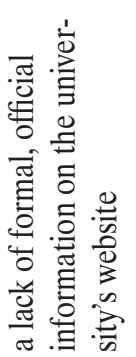

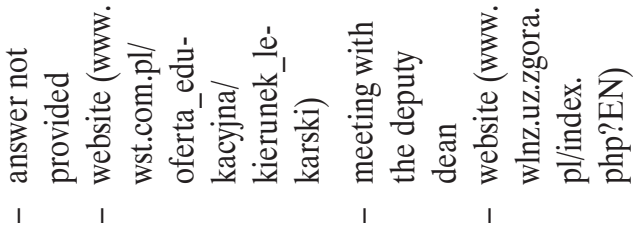

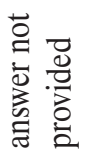

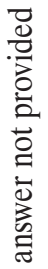

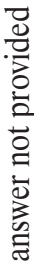

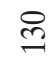
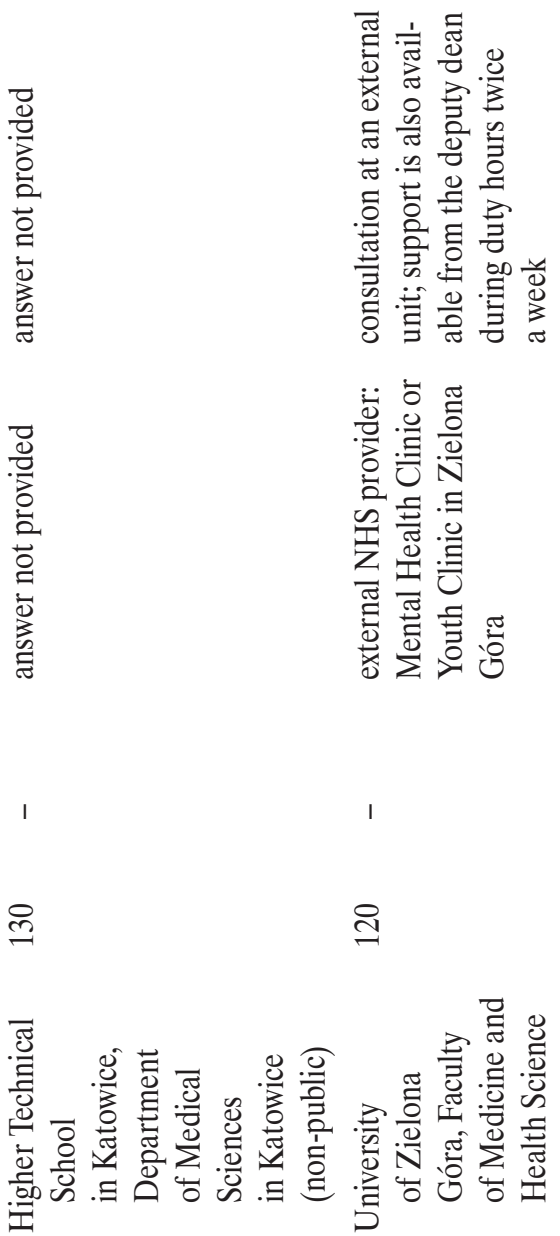

苛它芯

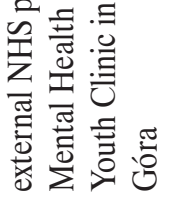

।

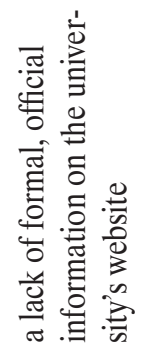

I

:

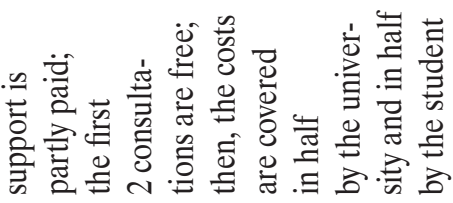

తิ สิ

ำ

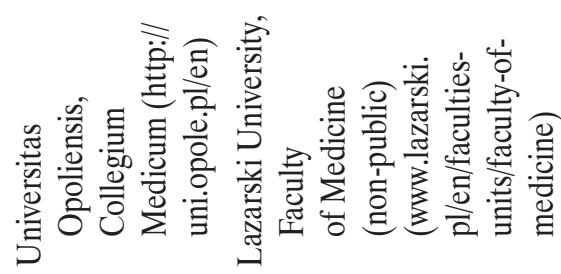

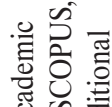

胥诘:

氙芯

.․ㅡㄹ

을

8 .

娄的宫

롱음

产员产

突芯

흐. 듈.

$\stackrel{0}{\equiv}$

.

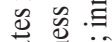

愛

해을

要 :

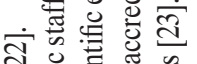

㱐.

过

药

完总若

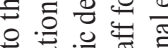

证

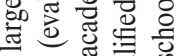

品兽焉

돈

4 计

वे की चू

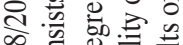

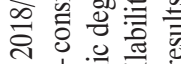

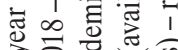

휼 चु

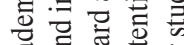

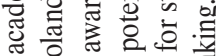

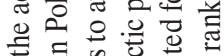

.

旸 要

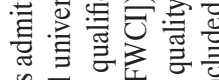

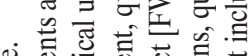

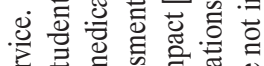

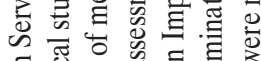

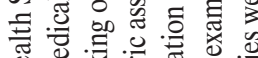

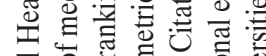

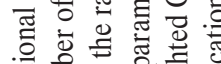

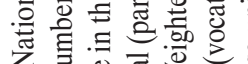

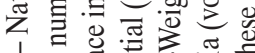

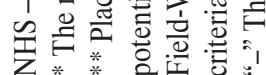


vidually, in accordance with its own diagnoses, needs and possibilities.

The authors have observed a trend that universities are divided into those where support is provided by internal units (usually didactic departments related to psychology and mental health clinics) with specialized structures, and those that outsource their support programs. Universities occasionally propose group formulas, such as workshops, facultative courses and lectures about coping.

They have also noted that psychological support is sometimes informal. A form of "on-call duty" during scientific and didactic consultations is offered. As they understand it, teachers provide support for students, thereby broadening their academic role by volunteering. It seems that this originates from bottom-up initiatives. It gives the impression that psychology teachers try to respond to students' needs to seek help. However, the growing scale of psychological problems among medical students justifies the need for the institutionalization and development of such support. Creating system solutions would optimize and increase the effectiveness of such assistance. The authors were very pleased by the opinion expressed that their letter convinced some university authorities of how important the issue of psychological assistance is for medical students, and perhaps, as they hope, it has initiated discussions in that regard.

\section{Financing}

Support is usually financed from the university budget. Not many schools have any additional funding, e.g., international students' tuition fees. As previously mentioned, in most cases, support is rather short-term and students are redirected to an external health provider. However, the authors are not sure whether students are prioritized in any way, e.g., given a faster entry under the National Health Service (NHS), after such redirection. The universities surveyed did not provide any information about this.

The Medical University of Warsaw presented the most comprehensive information (including a detailed report) on the fi- nancing model of the entire program. This report may be assumed to provide a valuable tip on how to prepare a financial model of psychological support for medical students.

Lazarski University, which has recently offered a nonpublic medical course, provides a curious solution by cofinancing external psychological consultations. Two meetings are complimentary and every follow-up is subsidized by $50 \%$. The question is whether outsourcing psychological support is a cheaper and better approach. The universities surveyed did not provide information about costs, so it is difficult to analyze and estimate this aspect. It would be interesting, inter alia, to compare the costs to the effects (e.g., the average price of a consultation). It seems that outsourcing is worth analyzing and considering in the context of providing psychological support. Major needs would be resolved at relatively small expenditure. However, the authors do not feel able or in a position to evaluate this matter from an economic point of view. This is due to the diverse structures and models of universities functioning in Poland. In addition, they would like to emphasize that outsourcing may not only be related to cost optimization, as an additional advantage could be the provision of professional help independent of the university.

\section{The problem of resistance and neutrality}

Students are afraid of stigmatization and environmental ostracism. Asking for help from a teacher with whom they may potentially have classes might be confusing. A teacher who is temporarily in a different role may not be sufficiently neutral for the student whose problems may apply to studies or a specific subject.

This may cause the activation of defense mechanisms and eventually lead to resistance towards this kind of help. At the same time, it seems that asking for support from a person a student knows, likes and trusts would be more straightforward. In addition, the authors wonder whether the social requirement/stereotype existing in this part of Europe that physicians should be infallible and omnipo- 
tent affects students' willingness to seek help. These research and interpretation questions remain unanswered.

\section{The main reasons for students}

\section{to report to psychological consultations}

The most frequent reasons for attending psychological consultations were:

- depression and anxiety symptoms,

- problems with adapting to studies,

- difficulties in interpersonal relationships,

- coping with stress,

- a loss of motivation to study,

- concentration difficulties,

- abuse of psychoactive substances,

- a family situation,

- "acting-out,"

- self-aggression,

- suicidal tendencies.

\section{Do universities really know what students need}

\section{and how to communicate with young people?}

The authors have the impression that, from the perspective of a student in crisis, the help itself and information about the potential support are not easily available. In other words, the "interface" is not student-friendly because communication is not transmitted by channels used by modern students. Finding useful information takes time and the website infrastructure is unintuitive. Some information is presented in display cases which students do not tend to see or give attention to.

The authors think that support planning should be cocreated with students as the beneficiaries of such help. Meanwhile, they have the impression that the current situation regarding communication and cooperation between universities and students is challenging. Moreover, there seems to be no doubt that keeping up with changes and trends that young people follow is becoming more and more difficult, as they regularly change and modify their communication channels. It is difficult to predict users' migration between portals and their popularity is dependent on age groups (e.g., Facebook, Instagram, Snapchat, TikTok). Popular social networks might offer an innovative strategy for addressing stress among students and for developing new methods of psychological support [24].

\section{CONCLUSIONS}

Psychological support for medical students should be flexible, and it should quickly adapt to emerging trends and needs, and refer to students' feedback, while taking into consideration their communication channels, the tools they use, and also their needs. A dynamic intervention center is a noteworthy solution for the future. A future model of that psychological support would be a kind of a "hub" between a university problem-solving facility and external health providers - a center organized as a transfer point, concentrating on the effective immediate or short-term activity. It would cooperate with the whole NHS-based support system in the region. Universities could sign appropriate agreements with external entities (outsourcing) and redirect students efficiently to a mental health specialist as a priority.

It seems that there is space for regulations here. After a review of the support programs applied at the leading medical universities in the world, the authors noticed many potential solutions which, once implemented, could enrich the available support package in Poland. What is more, they believe that the educational setting induced by the SARS-CoV-2 pandemic has accelerated the introduction and improvement of conventional solutions and e-solutions regarding the mental health of students in Poland. They are also convinced that the proper evaluation of these initiatives should be considered. Perhaps good solutions have already been developed and could inspire others.

Quick support would eliminate possible complications and more serious mental problems, and it may also prevent major crises in future doctors. 


\section{ACKNOWLEDGMENTS}

The authors are very grateful to the respondents for taking part in this research.

\section{REFERENCES}

1. Chou L-P, Li C-Y, Hu S. Job stress and burnout in hospital employees: comparisons of different medical professions in a regional hospital in Taiwan. BMJ Open. 2014;4(2):e004185, https://doi.org/10.1136/bmjopen-2013-004185.

2. Meerten M, Rost F, Bland J, Garelick AI. Self-referrals to a doctors' mental health service over 10 years. Occup Med (Chic Ill). 2014;64(3):172-6, https://doi.org/10.1093/occmed/ kqt177.

3. Rössler W. Stress, burnout, and job dissatisfaction in mental health workers. Eur Arch Psychiatry Clin Neurosci. 2012;262(2):65-9, https://doi.org/10.1007/s00406-012-0353-4.

4. Shanafelt TD, Boone S, Tan L, Dyrbye LN, Sotile W, Satele D, et al. Burnout and satisfaction with work-life balance among US physicians relative to the general US population. Arch Intern Med. 2012;172(18):1377-85, https:/doi. org/10.1001/ARCHINTERNMED.2012.3199.

5. Brennan J, McGrady A, Lynch DJ, Whearty K. Stress management intervention for first year medical students. Ann Behav Sci Med Educ. 2010;16(2):15-9, https://doi.org/10.1007/ BF03355126.

6. Rotenstein LS, Ramos MA, Torre M, Segal BJ, Peluso MJ, Guille $\mathrm{C}$, et al. Prevalence of depression, Depressive symptoms, and suicidal ideation among medical students. JAMA. 2016;316(21):2214, https://doi.org/10.1001/jama.2016.17324.

7. Dahlin M, Joneborg N, Runeson B. Stress and depression among medical students: a cross-sectional study. Med Educ. 2005;39(6):594-604, https://doi.org/10.1111/j.1365-2929. 2005.02176.x.

8. Tjia J, Givens JL, Shea JA. Factors associated with undertreatment of medical student depression. J Am Coll Heal. 2005;53(5):219-24, https://doi.org/10.3200/JACH.53.5.219-224.

9. Chew-Graham CA, Rogers A, Yassin N. "I wouldn't want it on my CV or their records": medical students' experiences of help-seeking for mental health problems. Med Educ. 2003;37(10):873-80, https://doi.org/10.1046/J.1365-2923.2003. 01627.X.

10. Kluczyńska S, Witkowska EM, Zabłocka-Żytka L, Sokołowska E. The mental health of Polish students - Selected positive and negative indicators. Postep Psychiatr Neurol. 2019;28:233-40, https://doi.org/10.5114/ppn.2019.92484.

11. Masiak J, Gupta N, Karakuła H, Perzyński A, Wallace BE. Depression amongst medical students. Curr Probl Psychiatry. 2012;13:89-92.

12. Force T. Educating Doctors to Provide High Quality Medical Care: A Vision for Medical Education in the United States. Washington, DC: Association of American Medical Colleges; 2004.

13. Cuff PA, Vanselow NA. Improving Medical Education: Enhancing the Behavioral and Social Science Content of Medical School Curricula. Washington, DC: National Academies Press (US).

14. Goldman ML, Shah RN, Bernstein CA. Depression and suicide among physician trainees: recommendations for a national response. JAMA Psychiatry. 2015;72(5):411-2, https:// doi.org/10.1001/jamapsychiatry.2014.3050.

15. Puthran R, Zhang MWB, Tam WW, Ho RC. Prevalence of depression amongst medical students: a meta-analysis. Med Educ. 2016;50(4):456-68, https://doi.org/10.1111/medu. 12962.

16. American Medical Students Association [Internet]. Chantilly: The Association, 2019 [cited 2019 Apr 1]. Staying Sane: Addressing the Growing Concern of Mental Health in Medical Students. Available from: https:/www.amsa.org/2015/09/ 08/staying-sane-addressing-the-growing-concern-of-mentalhealth-in-medical-students/.

17. Brazeau CM, Shanafelt T, Durning SJ, Massie FS, Eacker A, Moutier C, et al. Distress among matriculating medical students relative to the general population. Acad Med. 2014;89(11): 1520-5, https://doi.org/10.1097/ACM.0000000000000482.

18. Ludwig AB, Burton W, Weingarten J, Milan F, Myers DC, Kligler B. Depression and stress amongst undergraduate 
medical students. BMC Med Educ. 2015;15:141, https://doi. org/10.1186/s12909-015-0425-z.

19. The Polish Chamber of Physicians and Dentists [Internet]. Warszawa: The Chamber; 2019 [cited 2019 Apr 1]. Zestawienie liczbowe Lekarzy i Lekarzy Dentystów wg przynależności do okręgowej izby lekarskiej i tytułu zawodowego. Available from: https://old.nil.org.pl/_data/assets/pdf_ file/0007/134764/Zestawienie-nr-01.pdf.

20. OECD iLibrary [Internet]. Paris: OECD; 2019 [cited 2019 Apr 1]. Health Resources. Available from: https://doi. org/10.1787/4355e1ec-en.

21. Polish Central Statistical Office [Internet]. Warszawa: The Office; 2018 [cited 2019 Apr 1]. Average Gross Wage in the Fourth Quarter 2018. Available from: https://stat.gov.pl/ en/latest-statistical-news/communications-and-announce- ments/list-of-communiques-and-announcements/averagegross-wage-in-the-fourth-quarter-2018,281,21.html.

22. [Rozporządzenie Ministra Zdrowia z dnia 16 lipca 2018 r. w sprawie limitu przyjęć na kierunki lekarski i lekarsko-dentystyczny. J Laws 2018, item 1381]. Polish.

23. Perspektywy [Internet]. Warszawa: Wydawnictwo edukacyjne Perspektywy Press; 2019 [cited 2019 Apr 1]. [Ranking szkół wyższych. Perpektywy 2018]. Available from: https:// www.perspektywy.pl/RSW2018/ranking-uczelni-akademickich/rankingi-wg-typow/uczelnie-medyczne. Polish.

24. George DR, Dellasega C, Whitehead MM, Bordon A. Facebook-based stress management resources for first-year medical students: a multi-method evaluation. Comput Human Behav. 2013;29(3):559-62, https://doi.org/10.1016/J.CHB. 2012.12.008.

This work is available in Open Access model and licensed under a Creative Commons Attribution-NonCommercial 3.0 Poland License - http://creativecommons.org/ licenses/by-nc/3.0/pl/deed.en. 